\title{
The Integration of Family Planning with Other Health Services: A Literature Review
} CONTEXT: Integrating family planning services with other health services may be an effective way to reduce unmet
need. However, greater understanding of the evidence on integration is needed.

METHODS: Studies that evaluated the integration of family planning with any other type of health service were identified by searching five databases. To be included, studies had to have: been published in English between 1994 and 2009; used either a single-group pre-and posttest design or a two-group control or comparison design; and reported a family planning-related behavioral or reproductive health outcome.

RESULTS: Nine studies met the inclusion criteria. The integration interventions ranged from simple referrals between providers of existing services to fully integrated, community-based delivery of education and services. One evaluation used a quasi-experimental design; two used case-control comparison designs; two used combination designs; and the rest used either a single-group pre- and posttest design or a two-group cross-sectional design. Seven studies found improvements in family planning-related outcomes, although not all reported the significance of these changes; another reported mixed results and one found no effect. Of the studies that examined providers', clients'or community members' perspectives of integration, all reported overall satisfaction. No studies provided an economic analysis.

CONCLUSIONS: The evidence supporting the integration of family planning with other health services remains weak, and well-designed evaluation research is still needed. Future research should report outcomes for all health areas being integrated and should investigate in more detail the perspectives of providers, clients and community members and assess the cost-effectiveness of integration.

International Perspectives on Sexual and Reproductive Health, 2010, 36(4):189-196
By Anne Sebert

Kuhlmann,

Loretta Gavin and

Christine Galavotti

Anne Sebert

Kuhlmann is an independent consultant,

MANILA Consulting

Group, Inc., McLean,

VA, USA. Loretta

Gavin is health

scientist, Division of

Reproductive Health,

and Christine

Galavotti is chief,

Applied Sciences

Branch, Division of Reproductive Healthboth at the Centers for Disease Control and Prevention, Atlanta, GA, USA.
Despite decades of progress in improving the delivery and availability of family planning services, high levels of unmet need for family planning still exist in many countries. ${ }^{1}$ This suggests that novel approaches are needed to extend access to family planning services to women and couples who desire to limit or space their childbearing but are not currently using contraceptives. The integration of family planning with other health services may be one such approach. Although integration may seem logical, the results of efforts to integrate child ${ }^{2}$ or primary ${ }^{3}$ health care services with other services suggest that integration presents many logistic challenges and that caution is advisable. Shelton and Fuchs warn that the fragility of health systems in many countries can constrain effective integration of services. ${ }^{4}$ Therefore, an evidence base demonstrating the effectiveness of integration needs to be established before substantial investments are made in promoting integration as a means of fulfilling unmet need for family planning.

Numerous studies have examined the integration of family planning with programs for HIV/AIDS or other STIs. ${ }^{5-9}$ Other studies have explored integration of health services (in some cases family planning services) with

*We initially searched the Global Health database, which was subsumed under CABDirect during the course of the review. childhood immunization programs ${ }^{10}$ or intimate partner violence programs. ${ }^{11}$ Another study reviewed the integration of primary health care services in general. ${ }^{3}$ To our knowledge, however, no comprehensive review has been conducted examining integration of family planning services with any type of health service. Therefore, we reviewed the literature to understand the current state of knowledge about the effectiveness of such integration.

\section{METHODS}

We searched the peer-reviewed literature to identify quantitative studies conducted anywhere in the world that evaluated the integration of family planning services with any other type of health service. We established, a priori, two inclusion criteria for the studies in this review. First, the study had to report a family planning-related behavioral or reproductive health outcome, such as contraceptive prevalence or service utilization. Second, the evaluation study had to have either a single-group pre- and posttest design or a two-group control or comparison design. These criteria were established to make it easier to assess the strength of evidence regarding the effectiveness of integration.

The search covered five databases that abstract peerreviewed journals relevant to public health: PubMed, Embase, CABDirect, ${ }^{*}$ PsycINFO and Social Sciences Citation 
Index. We selected these databases to capture a broad range of geographic and disciplinary areas. To search the databases, we used the combination of a family planning-related term ("family planning," "birth spacing," "birth control," "contraception," "pregnancy planning" or "pregnancy prevention") and an integration-related term ("integration," "bundling" or "twinning"). We limited the search to articles published in English from 1994 to mid2009. At first, we conducted the search using a 10-year period (1999-2009), but because the number of eligible articles was small, we expanded the search period to 15 years.

Our search identified 581 unique abstracts, of which 80 were relevant to our topic. Two of us (ASK and LG) separately reviewed all relevant articles for inclusion, reaching consensus through discussion. Of the 80, many were commentaries or descriptive cross-sectional studies that did not meet the inclusion criteria. Ultimately, nine articles met both inclusion criteria and are included in the present analysis.*

In reviewing the nine articles, we paid special attention to the integration intervention and its evaluation. We could not identify an agreed-upon set of terms describing the distinguishing features of integration efforts, so we named and defined several potential approaches to integration before conducting the review. In an iterative process, we then refined the terms and their definitions to reflect how integration was implemented in the various studies.

The intervention characteristics that we considered included the type of health service that was integrated with family planning, the location of the integration (clinic, community or both) and the integration approach (Web Appendix Table 1). We classified integration approaches into five categories: referrals, community partnerships, service coordination, cross-training and structural approaches. In referral-based interventions, staff members providing one type of service encourage clients to receive or obtain the other service(s) from a separate set of providers in a clinic setting. In community partnerships, staff who provide a clinic-based service refer clients to specially trained community members or outreach workers to obtain one or more other services outside of the clinic setting (and vice versa). Service coordination entails clients' receiving multiple services delivered by multiple providers at the same site during a single visit (i.e., the "one-stop shopping" model). Cross-training involves expanding the training of staff so that they are able to provide more than one type of health service to a client during the same visit. Finally, structural integration refers to changing the infrastructure and administration of the relevant health services in order to make them more seamless-for example, by creating a single medical record for mothers and infants or eliminating rules by which family planning services are offered only

*Of the 71 remaining articles, 11 were reviews related to other topics or aspects of integration, 20 were editorials or commentaries on integration, 15 described general approaches to service delivery or integration (or tests of such approaches) and 25 detailed specific program experiences but either lacked a pre-post design or comparison group (11) or did not report any family planning outcomes (14) at certain times. More than one of these approaches to integration may be implemented simultaneously.

We used a tiered system adapted from the Guide to Community Preventive Services to rate the strength of each evaluation's design. ${ }^{12}$ The Guide presents a well-established system developed by the Centers for Disease Control and Prevention and its partners for reviewing evidence-based public health information. Our adaptation classified the strength of a study's design as being at one of four levels: greatest, moderate, fair or least. Study designs categorized as having the greatest strength used "concurrent comparison groups and prospective measurement of exposure and outcome." 12 The moderate tier consisted of retrospective designs, including case-control comparison designs. We labeled studies that combined a single-group pre-and posttest design with a cross-sectional comparison group, or that used multiple pre- and posttests without a comparison group (i.e., time series), as fair. Finally, those that used "single pre- and postmeasurement and no concurrent comparison group" or a two-group cross-sectional design were considered the least suitable for contributing to an evidence base. ${ }^{12}$ Studies with weaker designs, such as single-group cross-sectional, were not included in the review.

Finally, to examine the effect of the integration intervention on family planning-related outcomes, we assessed the magnitude and statistical significance of the reported changes in contraceptive prevalence or service utilization. If reported, the magnitude and statistical significance of changes in outcome variables for the other (nonfamily planning) health services were assessed as well. We also noted whether studies reported clients', providers' or community members' perspectives of the integrated services.

\section{RESULTS}

Of the nine articles included in the review, eight were published between 1999 and 2009. The nine studies suggest that the integration of family planning with other health services is taking place around the world, as Sub-Saharan Africa, Southeast Asia and South and Central America are all represented (Table 1). All of the studies were conducted in developing countries, although this was not a criterion for inclusion.

\section{Location and Approach}

The studies included both clinic- and community-based interventions, used a variety of approaches (Table 1) and were integrated with a wide range of other health services (Table 2, pages 192-193). Most frequently, family planning was integrated with some type of existing health service for mothers, children or both, such as the Expanded Programme on Immunizations. Other interventions integrated family planning with existing services for sexually active women, such as HIV/AIDS programs.

Two studies ${ }^{13,14}$ went beyond the typical focus of family planning integration efforts by integrating family planning with broad health interventions. Lundgren and colleagues reported on an intervention in El Salvador that, in 


\begin{tabular}{|c|c|c|c|c|c|c|c|c|c|c|c|}
\hline \multirow[t]{2}{*}{ Study } & \multirow[t]{2}{*}{ Country } & \multirow{2}{*}{$\begin{array}{l}\text { Strength } \\
\text { of study } \\
\text { design }\end{array}$} & \multicolumn{2}{|c|}{ Location } & \multicolumn{5}{|l|}{ Approach } & \multicolumn{2}{|c|}{ Family planning outcomes } \\
\hline & & & Clinic & $\begin{array}{l}\text { Com- } \\
\text { munity }\end{array}$ & Referrals & $\begin{array}{l}\text { Community } \\
\text { partnerships }\end{array}$ & $\begin{array}{l}\text { Service } \\
\text { coordi- } \\
\text { nation }\end{array}$ & $\begin{array}{l}\text { Cross- } \\
\text { training }\end{array}$ & Structural & $\begin{array}{l}\text { Improve- } \\
\text { ments } \\
\text { reported }\end{array}$ & $\begin{array}{l}\text { Statistical } \\
\text { significance } \\
\text { reported }\end{array}$ \\
\hline $\begin{array}{l}\text { Huntington } \\
\text { and Aplogan, } 1994^{18}\end{array}$ & Togo & Greatest & $x$ & & $x$ & & & & & Yes & Yes \\
\hline $\begin{array}{l}\text { Alvarado } \\
\text { et al., } 1999^{15}\end{array}$ & Chile & Moderate & $x$ & $x$ & & $x$ & $x$ & & $x$ & No & No \\
\hline $\begin{array}{l}\text { Fullerton } \\
\text { et al.,2003 } 200\end{array}$ & Ghana & Moderate & $\mathrm{x}$ & & & & & $x$ & & Yes & Yes \\
\hline $\begin{array}{l}\text { Bossyns } \\
\text { et al., } 2002^{16}\end{array}$ & Niger & Fair & $x$ & & & & & $x$ & $x$ & Yes & No \\
\hline $\begin{array}{l}\text { Lundgren } \\
\text { et al., } 2005^{14}\end{array}$ & El Salvador & Fair & & $x$ & & $x$ & & & & Mixed & Yes \\
\hline $\begin{array}{l}\text { Amin } \\
\text { et al., } 2001^{13}\end{array}$ & Bangladesh & $\begin{array}{l}\text { Phase 1:Fair } \\
\text { Phase 2:Least }\end{array}$ & $x$ & $x$ & & $x$ & & & & $\begin{array}{l}\text { Phase 1:Yes } \\
\text { Phase 2:Yes }\end{array}$ & $\begin{array}{l}\text { Phase 1:No } \\
\text { Phase 2:Yes }\end{array}$ \\
\hline $\begin{array}{l}\text { Adeokun } \\
\text { et al., } 2002^{17}\end{array}$ & Nigeria & Least & $x$ & & & & & $x$ & $x$ & Yes & No \\
\hline $\begin{array}{l}\text { Douthwaite } \\
\text { and Ward, } 2005^{20}\end{array}$ & Pakistan & Least & & $x$ & & $x$ & & & & Yes & Yes \\
\hline $\begin{array}{l}\text { Paxman } \\
\text { et al., } 2005^{21}\end{array}$ & India & Least & & $x$ & & $X$ & & & & Yes & No \\
\hline
\end{tabular}

an attempt to expand family planning participation among men, integrated family planning education and referrals with an existing water and sanitation program that included home visits and community meetings. ${ }^{14}$ Amin and colleagues described a collaboration in Bangladesh between a nongovernmental organization and the local government to provide microcredit assistance and childhood immunizations along with family planning education and referrals and nonclinical family planning commodities. ${ }^{13}$

Although many interventions had an explicit community component designed to reach potential family planning clients who might otherwise be missed by a static, clinic-based program, the extent of this component ranged widely, from health workers making home visits to community mobilization. In addition, two studies combined clinic and community-based intervention strategies. In the first, Alvarado and colleagues tested an intervention in Chile that trained community health workers to make home visits to pregnant women; the intervention also involved structural changes in clinic procedures, so that mothers and infants shared a clinical record and had dual appointments during the postpartum year. ${ }^{15}$ In contrast, the Bangladesh study started as a door-to-door intervention but shifted to include static, clinic-based integration. ${ }^{13}$

The methods of delivering integrated services varied. The five studies that featured community partnerships followed the model of having specially trained community members or outreach workers provide information, education and nonclinical services, while providing referrals for clinical services; none mentioned having clinic staff members refer clients to specially trained community members or outreach workers for additional services.

In addition to the Chile study, two other interventions involved substantial structural changes in how services were organized and administered. In Niger, special family planning clinics were abolished, and services were instead offered at a broader range of times and locations. ${ }^{16}$ In Nigeria, an integrated management information system for family planning and prevention of HIV and other STIs was developed and implemented. ${ }^{17}$

\section{Strength of Evaluation Study Designs}

The study by Huntington and Aplogan was the only one that met the criteria for having the greatest strength of study design; it was also the earliest published (1994). ${ }^{18}$ Both of the studies that received a moderate rating used case-control comparison designs, although the quality of the comparison group differed between the studies: The intervention and comparison groups were more comparable in Ghana than in Chile, and the Ghana study used a random sampling strategy whereas the Chile study used convenience sampling. ${ }^{15,19}$ Two of the three studies that received a fair rating ${ }^{13,14}$ combined single-group pre- and posttest measurement with two-group cross-sectional designs by conducting baseline surveys only with potential participants but then including both participants and nonparticipants in the follow-up survey; the third used multiple pre- and posttest measurements (i.e., time-series design) but did not include a comparison group at any measurement point. ${ }^{16}$ 
TABLE 2. Interventions, designs and results of studies assessing the impact of integrating family planning services with other health services, 1994-2009

\begin{tabular}{ll} 
Study & Intervention \\
\hline $\begin{array}{ll}\text { Adeokun et } \\
\text { al., } 2002^{17}\end{array}$ & • Family planning providers were \\
& trained to counsel clients on dual \\
& protection and provided female \\
& condoms (initially free, then for \\
& \$0.10), as well as HIV/STI \\
& prevention counseling \\
& -A management information \\
& system that included dual \\
& protection was developed and \\
& implemented \\
& • Providers were supervised by \\
& and met monthly with the training \\
& organization
\end{tabular}

Alvarado et al., $1999^{15}$

Amin et

al., $2001^{13}$

Bossyns et al., $2002^{16}$

Douthwaite and Ward, $2005^{20}$ postpartum follow-up visits - Community health workers conducted individual and group counseling, including two prenatal home visits, a maternity ward visit and monthly postpartum group sessions

- Intervention integrated family planning with microcredit and childhood immunization programs

- In phase 1, door-to-door education campaigns delivered nonclinical family planning and child immunizations; group meetings were held among microcredit recipients - Phase 2 added a package of clinic-based curative care and child and reproductive health services

- Family planning services were integrated with curative services, postnatal care and consultations for children younger than 5

- New operational instructions were created, including procedural changes (e.g. provision of six cycles of contraceptives), structural changes (e.g., elimination of dedicated family planning clinics) and attitudinal changes (e.g., offering family planning to all eligible women) - Monthly supervisory visits to all health centers

- Lady Health Workers delivered maternal and child services in homes and were responsible for
Study design, data collection and sample

- Single pre- and posttest design using mixed methods; no comparison group

- At baseline, evaluators made structured observations of 325 provider-client interactions and conducted exit interviews with 175 clients; at follow-up, they observed 289 provider-client interactions, conducted exit interviews with 289 clients, interviewed 10 providers and conducted focus groups with providers, clients and male community representatives

- Service statistics were collected from all clinics

- Service providers interviewed 47 dualprotection acceptors at follow-up

- Case-control design

- Clinical record review of 200 women living in intervention clinic neighborhood who had a pregnancy and 200 mothers and infants attending first postnatal follow-up visit at control clinic - Investigators conducted in-depth interviews with 35 women attending intervention clinic and four providers at the clinic, as well as three focus groups with women attending the clinic promoting use of family planning providing pills and condoms, and making referrals for injections, IUDs and sterilization
- In phase 1, single pre- and posttests were done in experimental areas ( 656 and 2,105 women surveyed, respectively), and posttests were done in comparison areas (1,721 women) - In phase 2, a posttest survey was conducted among 1,068 women in experimental areas and 700 women in comparison areas

- Multiple pre- and posttest design;no comparison group

- Data obtained from five years of district service utilization statistics (intervention was implemented at the end of the third year) and from direct observation in three health centers before $(\mathrm{N}=277)$ and after $(\mathrm{N}=403)$ implementation
- Posttest design in intervention and comparison areas

- Sample consisted of 3,346 married rural women aged 15-49 in intervention areas and 931 such women in control areas

- Additional comparisons made with national survey
Family planning and other outcomes

- The proportion of visits at which condoms were distributed increased from $2 \%$ to $9 \%$ ( $p$ value not reported)

- The proportion of new clients aware of dual protection increased from $8 \%$ to $50 \%$ (p value not reported)

- The proportion of new client visits in which tailored dual protection counseling was provided increased from $28 \%$ to $67 \%(p<.05)$

- Proportion of women who initiated contraception during the postpartum year was similar for intervention and control clinics ( $92 \%$ vs. $96 \%$; p value not reported)

- Providers and clients at intervention clinic reported high levels of satisfaction with the program (those at control clinic were not surveyed)

- At six months postpartum, $74 \%$ of infants at intervention clinic and $10 \%$ of those at control clinic were exclusively

breast-fed $(p=.0001)$

- Despite similar birth weights and lengths, infants at intervention clinic were heavier and longer than those at control clinic at six months ( $p=.03$ and $p<.001$, respectively) and 12 months ( $<$ <.001 for both)

- In phase 1, contraceptive prevalence increased from $28 \%$ to $53 \%$ among women in experimental areas and was higher in experimental than control areas ( $53 \%$ vs. $38 \%$ ); p values were not reported.

- At end of phase 2 , microcredit members were more likely than nonmembers to report current contraceptive use (odds ratio, 1.5; $\mathrm{p}<.01)$ and to use a static clinic for family planning $(1.70 ; p<.05)$, after adjustment for background characteristics

- Diphtheria, pertussis and tetanus immunization coverage among chlldren increased in experimental areas from $83 \%$ to $94 \%$, but was similar at follow-up to coverage in control areas (96\%). Similarly, coverage of tetanus immunization among women increased in experimental areas from $81 \%$ to $90 \%$, but was similar at follow-up to coverage in control areas (86\%); $p$ values were not reported.

- Annual no. of couple-years of contraceptive protection increased between the three years before the intervention (487-566) and the two years after (920-1109).

- The annual no. of new contraceptive users also increased, from 489-568 to 1,496-1,509.

- P values were not reported for either outcome

- Non-family planning outcomes not reported
- Proportion of women using modern contraceptives was higher in intervention areas (20\%) than in control areas $(14 \%)$ or in a national survey (15\%; p values not reported)

-Women in intervention areas were more likely than those in control areas to report use of modern reversible contraceptives (adjusted odds ratio, $1.50 ; p=.03$ )

- Non-family planning outcomes not reported 
TABLE 2. contInued

\begin{tabular}{|c|c|c|c|}
\hline Study & Intervention & Study design, data collection and sample & Family planning and other outcomes \\
\hline $\begin{array}{l}\text { Fullerton et } \\
\text { al., } 2003^{19}\end{array}$ & $\begin{array}{l}\text { - Family planning providers in } \\
\text { eastern Ghana were trained to } \\
\text { integrate STI and postabortion } \\
\text { care into service delivery } \\
\text { - Training targeted providers in } \\
\text { selected districts in region }\end{array}$ & $\begin{array}{l}\text { - Case-control design; conducted in 1996-1998 } \\
\text { - Data obtained from observations in } 24 \text { intervention } \\
\text { and } 19 \text { comparison facilities, clinical record reviews } \\
\text { in all facilities, and interviews with } 48 \text { providers or } \\
\text { clinic managers and } 37 \text { clients }\end{array}$ & $\begin{array}{l}\text { - Annual no. of family planning clients increased in case facilities } \\
\text { (from } 2,300 \text { to } 3,000 \text { ) but showed little change in comparison } \\
\text { facilities (from 2,600 to } 2,700 \text { ); p values not reported } \\
\text { - No. of continuing family planning clients seen per month increased } \\
\text { in case facilities (from } 113 \text { to } 164 ; p=.02 \text { ) but not in comparison } \\
\text { facilities; however, the no. of new or continuing clients did not differ } \\
\text { between case and control facilities } \\
\text { - No. of case facilities providing STI services increased from 6-7 to } \\
10-11 \text {, and annual no. of STI clients at these facilities increased from } \\
50 \text { to } 340 ; \text {; only two comparison facilities provided STI services } \\
\text { - Intervention facilities provided postabortion care to } 136-426 \text { clients } \\
\text { per year; no comparison facilities reported providing such services }\end{array}$ \\
\hline $\begin{array}{l}\text { Huntington } \\
\text { and Aplogan, } \\
1994^{18}\end{array}$ & $\begin{array}{l}\text { - Before administering vaccines } \\
\text { as part of the Expanded } \\
\text { Programme on Immunizations } \\
\text { (EPI), providers made three simple } \\
\text { statements referring mothers to } \\
\text { family planning services available } \\
\text { at the same visit and facility } \\
\text { (but from different providers) }\end{array}$ & $\begin{array}{l}\text { - Two-group, quasi-experimental design } \\
\text { - Stratified sample of } 16 \text { urban and rural clinics, } \\
\text { which were randomly assigned to be test or control } \\
\text { clinics (randomization procedures not described) } \\
\text { - Pre- and posttest exit interviews were conducted } \\
\text { with } 1,000 \text { randomly selected mothers whose } \\
\text { children had been vaccinated (randomization } \\
\text { procedures not described) } \\
\text { - Posttest, self-administered questionnaires } \\
\text { were completed by all EPI providers in test clinics } \\
\text { - Service utilization data obtained from all clinics }\end{array}$ & $\begin{array}{l}\text { - Proportion of women who reported that family planning was } \\
\text { mentioned during EPI services increased from } 9 \% \text { to } 21 \% \\
\text { in test clinics but was stable (about } 9 \% \text { ) in control clinics } \\
\text { ( } p \text { value not reported) } \\
\text { - Mean no. of new family planning acceptors per month increased } \\
\text { in test clinics (from } 200 \text { to } 307 ; p<.001 \text { ) but not in control clinics } \\
\text { - Mean no. of family planning clients per month increased in test } \\
\text { clinics (from } 1,035 \text { to } 1,311 ; p<.0001 \text { ) but not in control clinics } \\
\text { - Mean no. of vaccine doses administered per month increased } \\
\text { in both test and control clinics } \\
\text { - Ninety percent of EPI providers felt referrals affected EPI } \\
\text { consultations; of these, } 96 \% \text { thought the effect was positive }\end{array}$ \\
\hline $\begin{array}{l}\text { Lundgren et } \\
\text { al., } 2005^{14}\end{array}$ & $\begin{array}{l}\text { - Integration incorporated family } \\
\text { planning services (provision of } \\
\text { information, condoms, CycleBeads } \\
\text { and referrals) with existing water } \\
\text { and sanitation projects in rural } \\
\text { villages } \\
\text { - Community members were } \\
\text { educated through group talks by } \\
\text { NGO staff and volunteers, and } \\
\text { home visits by trained volunteers }\end{array}$ & $\begin{array}{l}\text { - Single pre- and posttest in intervention } \\
\text { area, plus posttest with comparison group } \\
\text { - Independent samples of households were } \\
\text { surveyed at baseline ( } \mathrm{N}=341) \text { and follow-up } \\
(\mathrm{N}=364)\end{array}$ & $\begin{array}{l}\text { - Prevalence of contraceptive use in intervention area increased from } \\
44 \% \text { to } 63 \% \text { ( } p \leq .001 \text { ) among men but did not increase among } \\
\text { women } \\
\text { - At follow-up, contraceptive use among those exposed to the } \\
\text { intervention was similar to that among those not exposed } \\
\text { for both women ( } 57 \% \text { vs. } 48 \% \text { ) and men ( } 65 \% \text { vs. } 62 \%) \\
\text { - Non-family planning outcomes were not reported }\end{array}$ \\
\hline $\begin{array}{l}\text { Paxman et } \\
\text { al., } 2005^{21}\end{array}$ & $\begin{array}{l}\text { - Family planning integrated } \\
\text { with child health services } \\
\text { through India's Local Initiatives } \\
\text { Program } \\
\text { - Program partnered community } \\
\text { teams with government health } \\
\text { staff, development workers and } \\
\text { local leaders; community members } \\
\text { were involved in planning, imple- } \\
\text { mentation and resource } \\
\text { mobilization } \\
\text { - Women received information, } \\
\text { clinic referral and resupplies of } \\
\text { pills and condoms }\end{array}$ & $\begin{array}{l}\text { - Single pre- and posttest design } \\
\text { - Three NGOs working in different project areas each } \\
\text { conducted baseline and follow-up surveys and } \\
\text { had leeway to implement their own approach and } \\
\text { instrument; two used the World Health Organization } \\
\text { and } 30 \text {-household-cluster survey approach, and the } \\
\text { other used a baseline sample of 7,400 men and } \\
\text { women } \\
\text { • Other details about survey design, sample size } \\
\text { and sample characteristics not provided } \\
\text { - Additional comparisons made to a national } \\
\text { survey conducted around baseline }\end{array}$ & $\begin{array}{l}\text { - Contraceptive prevalence increased by } 10-39 \text { percentage points } \\
\text { in the three project areas ( } \mathrm{p} \text { values not reported) } \\
\text { - The proportion of pregnant women who received complete antenatal } \\
\text { care services increased by } 22-49 \text { percentage points in the three areas } \\
\text { (p values not reported) } \\
\text { - The proportion of children fully immunized increased by } 27-42 \\
\text { percentage points in the three areas ( } p \text { values not reported) }\end{array}$ \\
\hline
\end{tabular}

\section{Outcomes}

- Family planning-related measures. Studies of interventions that focused on clinic-based components tended to report service utilization outcomes, while those with community-based components tended to report contraceptive use or prevalence data. Seven studies ${ }^{13,16-21}$ reported improvements in a behavioral or reproductive health outcome related to family planning, although not all of these studies reported the significance of these improvements. The other two reported either mixed results in family planning-related outcomes ${ }^{14}$ or found no improvements in these outcomes. ${ }^{15}$ No study reported that integration had a negative impact on a family planning-related outcome.

The quasi-experimental study and one of the casecontrol studies reported statistically significant increases in the mean number of new ${ }^{18}$ and continuing ${ }^{19}$ family planning clients in intervention clinics, while the comparison clinics reported no such increases. In Pakistan, use of reversible, modern contraceptives was significantly greater among respondents in intervention areas than among those in comparison areas, even after adjustment for community, household and individual characteristics. ${ }^{20}$ All three studies reported the statistical significance of their family planning-related outcomes.

Several other studies reported large percentage point increases in family planning-related outcomes. For example, self-reported contraceptive prevalence increased by 10-39 percentage points in India ${ }^{21}$ and by 25 percentage points in Bangladesh; ${ }^{13}$ the number of family planning visits in which condoms were distributed increased by approximately seven percentage points in Nigeria; ${ }^{17}$ and a composite index of contraceptive uptake increased from less 
than $1 \%$ to $23-29 \%$ in Niger (not shown). ${ }^{16}$ The statistical significance of these increases was not reported, however, making it difficult to assess their relevance.

Lundgren and colleagues reported mixed results in family planning-related outcomes. ${ }^{14}$ They found an increase in self-reported contraceptive use among male program participants, but not among female participants. Furthermore, at follow-up, contraceptive use did not differ between program participants and nonparticipants among either men or women. Moreover, because of the study design, the possibility cannot be ruled out that the changes in men's contraceptive use at follow-up were due to historical events in El Salvador instead of the intervention.

Alvarado and colleagues' case-control study of service integration in Chile ${ }^{15}$ did not find a positive effect on any family planning-related outcome. The contraceptive initiation rate in the intervention clinic was similar to that in the comparison clinics, despite the availability of a broader range of contraceptive methods at the intervention clinic. Furthermore, the intervention clinic initially offered contraceptives free of charge, while the comparison clinics charged a small fee. However, the intervention clinic did report significantly better outcomes than the comparison clinic on measures of exclusive breast-feeding and infant weight and length.

- Other outcomes. Some studies reported indicators of integration success and acceptability beyond those related to family planning (e.g., outcomes for other health services, client perspectives of the integrated services). All six of the studies that reported outcomes related to the other health services involved in the integration reported improvements in those outcomes. ${ }^{13,15,17-19,21}$ However, the significance of these findings was not always reported.

Similarly, all three of the studies that reported providers', clients' or community members' perspectives concerning the integration intervention found positive reactions (not shown). ${ }^{14,15,18}$ In El Salvador, nearly all participants thought integrating family planning information into water and sanitation programming was beneficial. ${ }^{14}$ In Togo and Chile, most providers felt that integration enhanced service provision. ${ }^{15,18}$ However, the studies that reported clients' and providers' reactions to the intervention provided only limited information; for example, they did not discuss providers' or participants' perceptions of the potential disadvantages and challenges of integration.

\section{DISCUSSION}

Evaluations of integration efforts have been conducted around the world, and these interventions have taken various forms. Most efforts focused on integrating family planning with other reproductive, sexual or child health services, but a few attempted to integrate family planning with services that extended beyond traditional health provision. Furthermore, no single model of integration exists. Although all of the interventions integrated, bundled or paired different health services with family planning, each did so in a unique way-the services that were integrated, their location and the approach to integration all varied.

This lack of consensus about the nature of integration complicates the dialogue about how best to do it. As discussions concerning the value of integration and its various forms continue, there is a need to refine definitions of integration and to clarify approaches. As an initial step toward a common taxonomy, we have presented terminology to classify the various locations and approaches. This taxonomy may need to be refined and expanded as our knowledge about integration increases; however, the use of common terminology should make it easier to develop an evidence base for integration and for providers, program implementation staff and researchers to share experiences.

Although it makes sense that integration should result in fewer missed opportunities for providing relevant services, and in potentially greater efficiency in service delivery, the data supporting these claims remain insufficient. Our study, like previous reviews of integration efforts, 3,7 found that the overall quality of the studies was often poor, as many had a single-group or cross-sectional design. Thus, although these studies contribute to the knowledge base about integration and can help generate hypotheses for future research, their contribution to establishing an evidence base on the effectiveness of integration in improving family planning outcomes is limited. Of note, however, is that two of the three studies with the strongest designs reported significant improvements in family planning-related outcomes.

While the general weakness of the study designs limits one's ability to establish causality, the consistency of the results suggests that integration has positive effects on family planning-related outcomes. Summarizing the overall magnitude of those effects is difficult, however, because of differences in approaches, study designs, outcome variables and reported information. This review highlights the need for well-designed, well-executed evaluation research to determine the effectiveness of integration and the best approaches to implementation.

Several factors may be contributing to the dearth of high-quality evaluation research on integration. First, in the wake of the 1994 International Conference on Population and Development, integration has often been assumed to be an effective strategy (although some have cautioned against this assumption ${ }^{4}$ ). In an environment where integration is thought to be an inherently positive model of service delivery, investing time and resources in high-quality evaluation may not be a priority. Second, donor commitment to family planning as a global public health issue waned during the years covered by this review, ${ }^{22}$ potentially further decreasing the resources available for evaluation research on family planning-related integration. Finally, integration interventions often include a community component, and designing and implementing evaluations that include adequate comparison or control groups in a community setting can be challenging. While this review included only a small number of studies, the three that had the strongest study designs were pri- 
marily clinic-based interventions; three of the four with the weakest designs were exclusively community-based interventions or had a significant community component.

The studies reviewed here were selected, in part, because they reported a quantitative outcome relevant to family planning programs. Other indicators of potential program success and acceptability are also important to understand. Although data were limited, most providers, clients and community members reacted favorably to integration efforts. Future research should include further assessment of clients', providers' and community members' perspectives on integrated services, such as their views concerning the conditions under which integration may or may not be feasible or acceptable (e.g., at fixed locations vs. outreach sessions), ways to avoid or offset potential costs of integration (such as long waiting times) and strategies for better integrating clinic- and community-based services.

Where reported, the other health services that were integrated with family planning showed improved or stable outcomes; none indicated a decline. Although none of the evidence reviewed here suggests that integration has a negative effect on other health services, having good data on all health services involved in integration interventions is vital. Ideally, integration would result in synergistic benefits for all services. For example, the study in Bangladesh integrated family planning with microcredit programs, which have been shown to reduce the economic and social vulnerability of women; such vulnerability often leads to risky sexual behaviors. ${ }^{23}$ It is likely that women who have become empowered through microcredit programs are more likely than other women to use family planning services, and that improved access to these services would further reinforce the empowerment of microcredit program participants. Yet to confirm this, good quality data on utilization of all services involved are essential.

Furthermore, none of the studies we reviewed addressed the issue of cost-effectiveness. Integration is generally assumed to reduce costs, especially if it involves service coordination or cross-training. Yet, the lack of data on the efficiency and costs of integration is glaring. Before interventions are adopted on a broad scale, we need to know whether integration makes economic sense and whether certain integration strategies are more cost-effective than others.

The results of this review are subject to two main limitations. First, the search was limited to articles published in English. Additional evaluations of family planning integration efforts may have been published in other languages. Second, because this review focused on peerreviewed literature, the potential for publication bias exists. Studies with significant findings are more likely than those with negative results to be submitted for peer review and, as a result, to be published. ${ }^{24}$ Therefore, the pattern of results reported here may overestimate the true effect of integration interventions.

In conclusion, current evidence suggests that integration of family planning with other health services may be beneficial. However, before integration is embraced as a broad-scale strategy to address the high levels of unmet need for family planning around the world, well-designed and properly executed evaluation research is needed to establish an evidence base for integration. Future research should investigate providers', clients' and community members' perspectives on the integrated services, report health outcomes for all services being integrated and evaluate the cost-effectiveness of integration. Understanding the impact of various integration strategies on expanding the reach of services, on the efficiency and costs of service delivery and on the overall impact on both family planning and other health outcomes would be extremely useful. The potential for benefit is clear, but the evidence base for whether and how to most effectively implement integration to obtain those benefits remains weak.

\section{REFERENCES}

1. Westoff CF, New estimates of unmet need and the demand for family planning, DHS Comparative Reports, Calverton, MD, USA: Macro International, 2006, No. 14

2. Bryce J et al., Programmatic pathways to child survival: results of a multi-country evaluation of integrated management of childhood illness, Health Policy and Planning, 2005, 20(Suppl. 1):i5-i17.

3. Briggs CJ and Garner P, Strategies for integrating primary health services in middle- and low-income countries at the point of delivery, Cochrane Database of Systematic Reviews, 2006, Issue 2, No. CD003318.

4. Shelton JD and Fuchs N, Opportunities and pitfalls in integration of family planning and HIV prevention efforts in developing countries, Public Health Reports, 2004, 119(1):12-15.

5. Church K and Mayhew SH, Integration of STI and HIV prevention, care, and treatment into family planning services: a review of the literature, Studies in Family Planning, 2009, 40(3):171-186.

6. Rutenberg N and Baek C, Field experiences integrating family planning into programs to prevent mother-to-child transmission of HIV, Studies in Family Planning, 2005, 36(3):235-245.

7. Askew I and Maggwa NB, Integration of STI prevention and management with family planning and antenatal care in Sub-Saharan Africa-what more do we need to know? International Family Planning Perspectives, 2002, 28(2):77-86.

8. Dehne KL, Snow R and O'Reilly KR, Integration of prevention and care of sexually transmitted infections with family planning services: What is the evidence for public health benefits? Bulletin of the World Health Organization, 2000, 78(5):628-639.

9. Mayhew S, Integrating MCH/FP and STD/HIV services: current debates and future directions, Health Policy and Planning, 1996, 11(4):339-353

10. Wallace A, Dietz V and Cairns KL, Integration of immunization services with other health interventions in the developing world: what works and why? Systematic literature review, Tropical Medicine $E$ International Health, 2009, 14(1):11-19.

11. Colombini M, Mayhew S and Watts C, Health-sector responses to intimate partner violence in low-and middle-income settings: a review of current models, challenges and opportunities, Bulletin of the World Health Organization, 2008, 86(8):635-642.

12. Briss PA et al., Developing an evidence-based Guide to Community Preventive Services-methods, American Journal of Preventive Medicine, 2000, 18(Suppl. 1):35-43.

13. Amin R et al., Integration of an essential services package (ESP) in child and reproductive health and family planning with a microcredit program for poor women: experience from a pilot project in rural Bangladesh, World Development, 2001, 29(9):1611-1621.

14. Lundgren RI et al., Cultivating men's interest in family planning in rural El Salvador, Studies in Family Planning, 2005, 36(3):173-188. 
15. Alvarado R et al., Integrated maternal and infant health care in the postpartum period in a poor neighborhood in Santiago, Chile, Studies in Family Planning, 1999, 30(2):133-141.

16. Bossyns P, Miyé H and Van Lerberghe W, Supply-level measures to increase uptake of family planning services in Niger: the effectiveness of improving responsiveness, Tropical Medicine $\&$ International Health, 2002, 7(4):383-390

17. Adeokun L et al., Promoting dual protection in family planning clinics in Ibadan, Nigeria, International Family Planning Perspectives, 2002, 28(2):87-95.

18. Huntington D and Aplogan A, The integration of family planning and childhood immunization services in Togo, Studies in Family Planning, 1994, 25(3):176-183

19. Fullerton J, Fort A and Johal K, A case/comparison study in the Eastern Region of Ghana on the effects of incorporating selected reproductive health services on family planning services, Midwifery, 2003, 19(1):17-26

20. Douthwaite $M$ and Ward $P$, Increasing contraceptive use in rura Pakistan: an evaluation of the Lady Health Worker Programme, Health Policy and Planning, 2005, 20(2):117-123.

21. Paxman JM et al., The India Local Initiatives Program: a model for expanding reproductive and child health services, Studies in Family Planning, 2005, 36(3):203-220.

22. Speidel JJ et al., Making the Case for U.S. International Family Planning Assistance, Baltimore, MD, USA: Population Reference Bureau, 2009, <http://www.prb.org/pdf09/makingthecase.pdf>, accessed Aug. 31, 2010.

23. Pronyk PM et al., A combined microfinance and training intervention can reduce HIV risk behaviour in young female participants, AIDS, 2008, 22(13):1659-1665.

24. Dickersin K, Min Y-I and Meinert CL, Factors influencing publication of research results: follow-up of applications submitted to two institutional review boards, Journal of the American Medical Association, 1992, 267(3):374-378.

\section{RESUMEN}

Contexto: Integrar los servicios de planificación familiar con otros servicios de salud puede ser una forma efectiva de reducir la necesidad insatisfecha. Sin embargo, se requiere una mayor comprensión de la evidencia existente sobre la integración.

Métodos: Se identificaron mediante la búsqueda en cinco bases de datos los estudios que han evaluado la integración de la planificación familiar con cualquier otro tipo de servicio de salud. Para ser incluidos, los estudios tenían que haber: sido publicados en inglés entre 1994 y 2009; haber usado un diseño ya sea de grupo simple pre y post prueba, o un diseño de control y comparación de dos grupos; $y$ haber reportado un resultado de comportamiento relacionado con la planificación familiar o con la salud reproductiva.

Resultados: Nueve estudios cumplieron con los criterios de inclusión. Las intervenciones de integración variaron desde simples referencias entre prestadores de servicios existentes, hasta la suministración comunitaria de educación y servicios completamente integrados. Una evaluación usó un diseño cuasi-experimental; dos usaron diseños comparativos caso-control; dos usaron diseños de combinación; y el resto usó un diseño ya sea de grupo simple pre y post prueba, o un diseño transversal de dos grupos. Siete estudios detectaron mejoras en los resultados relacionados con la planificación familiar, aunque no todos re- portaron la significancia estadística de esos cambios; otro más reportó resultados mixtos y uno no encontró efecto alguno. De los estudios que reportaron sobre las opiniones de los prestadores de servicios, clientes o miembros de la comunidad sobre la integración, todos reportaron una satisfacción general. Ningún estudio proporcionó un análisis económico.

Conclusiones: La evidencia que apoya la integración de la planificación familiar con otros servicios de salud sigue siendo débil; y todavía se necesita investigación evaluativa bien diseñada. Futuras investigaciones deben informar sobre resultados para todas las áreas de salud que estén siendo integradas y deben investigar en mayor detalle las opiniones de prestadores de servicios, clientes y miembros de la comunidad, así como evaluar el costo-efectividad de la integración.

\section{RÉSUMÉ}

Contexte: L'intégration de services de planification familiale aux autres prestations de santé peut être un moyen efficace de réduction du besoin non satisfait. Une meilleure compréhension des données d'intégration est cependant nécessaire.

Méthodes: Les études qui évaluent l'intégration de la planification familiale à tous autres types de prestations de santé ont été identifiées par recherche dans cinq bases de données. Les critères d'inclusion suivants ont été appliqués: publication en anglais entre 1994 et 2009; plan pré-et posttest à groupe unique ou plan de contrôle ou comparaison à deux groupes; et rapport de résultat comportemental ou de santé génésique lié à la planification familiale.

Résultats: Neufétudes se sont avérées conformes aux critères d'inclusion. Les interventions d'intégration vont de simples services d'orientation entre prestataires de services existants à l'intégration totale d'une éducation et de services communautaires. Une évaluation repose sur un plan quasi-expérimental; deux sur un plan de comparaison avec contrôle; deux sur un plan combiné; et le reste soit sur un plan pré-et posttest à groupe unique ou un plan transversal à deux groupes. Sept études observent des améliorations de résultats ayant trait à la planification familiale, bien qu'elles ne fassent pas toutes état de l'importance du changement observé; une fait état de résultats mixtes et une n'observe aucun effet. Parmi les études présentant les perspectives des prestataires, des clientes ou des membres de la communauté sur l'intégration, toutes font état d'une satisfaction générale. Aucune des études ne présente d'analyse économique.

Conclusions: Les données au soutien de l'intégration de la planification familiale aux autres services de santé demeurent faibles et une recherche d'évaluation bien conçue reste nécessaire. La recherche à venir devra faire état des résultats observés sur tous les plans de santé intégrés. Elle devra examiner de manière plus approfondie les perspectives des prestataires, des clientes et des membres de la communauté et évaluer la rentabilité de l'intégration.

Author contact: Lcg6@edc.gov 